\title{
СУЧАСНІ ПІДХОДИ ДО ТИПОЛОГІї І СТРУКТУРИ ЗАНЯТТЯ ПРИ ВИВЧЕННІ КЛІНІЧНИХ ДИСЦИПЛІН У МЕДИЧНИХ ВНЗ
}

\author{
С. Л. Стефанко \\ ДВНЗ “Івано-Франківський наиіональниймедичний університет”
}

\section{MODERN APPROACHES TO THE TYPOLOGY AND STRUCTURE OF THE STUDYING OF CLINICAL DISCIPLINES IN MEDICAL HIGHER EDUCATIONAL INSTITUTIONS}

\author{
S. L. Stefanko
}

\author{
SHEI "Ivano-Frankivsk National Medical University"
}

\begin{abstract}
Використання інтерактивних форм навчання в процесі вивчення клінічних дисциплін збільшує багаж знань студента з одночасним підвищенням пізнавальної здатності, надає йому творчу самостійність, розширюс обсяг набутих практичних навичок. Інтерактивні моделі забезпечують творчу активність студентів, допомагають формувати і розвивати професійне мислення.
\end{abstract}

Using of interactive forms of learning in the process of studying of the clinical disciplines increases the amount of knowledge of students with an increasing of cognitive ability, gives them the creative independence, expands the volume of acquired skills. Interactive models provide the creative activity of students, help to shape and develop the professional thinking.

Вступ. Аналіз вітчизняних і зарубіжних досліджень показує, що завдання підготовки фахівців нового покоління, у тому числі і медичних кадрів, не може бути повною мірою вирішене традиційними стандартними методами навчання [1]. Традиційні методи навчання студентів спрямовані, в основному, на одержання, розширення і поглиблення знань шляхом подачі інформації, її відтворення та конкретних професійних дій за готовим алгоритмом, $і €$ явно недостатніми. Ці методи дуже мало зачіпають основну ланку пізнавальної діяльності студентів - мислення [2].

Для поліпшення якості підготовки фахівців виникає необхідність застосування сучасних активних методів навчання, які забезпечують творчу активність студентів, спрямованих на формування і розвиток професійного мислення, здатності до засвоєння ними нових способів професійної діяльності.

Спочатку викладачеві треба визначити, що він планує зробити на занятті, а потім - як і якими способами. У педагогіці розрізняють кілька моделей навчання [3]: 1) пасивна - учень виступає в ролі “об'єкта” навчання (слухає і дивиться); 2) активна - учень виступає “суб' єктом” навчання (самостійна робота, творчі завдання); 3) інтерактивна (процес навчання здійснюється в умовах постійної, активної взаємодії всіх студентів і викладача).

(C) С. Л. Стефанко
Суть інтерактивного навчання полягає в тому, що навчальний процес організований таким чином, що всі студенти виявляються залученими в процес пізнання. Вони мають можливість зрозуміти і відчувати те, що вони знають, та переконатися, чи вміють та можуть правильно застосувати свої знання та вміння.

Використання інтерактивної моделі навчання передбачає моделювання життєвих ситуацій, використання рольових ігор, спільне вирішення проблем. Існує величезна кількість технологій інтерактивного навчання. Ось лише перелік деяких з них [4]: 1) робота в парах; 2) карусель; 3) робота в малих групах; 4) акваріум; 5) суд від свого імені; 6) рольова (ділова) гра; 7) займи позицію; 8) дискусія; 9) дебати.

Основна частина. На кафедрі акушерства та гінекології успішність процесу навчання на лекціях, щоденних опитуваннях і семінарських заняттях, елективних курсах досягається спільними зусиллями викладача та студентської аудиторії.

Структура заняття визначається метою і змістом досліджуваного матеріалу і не може складатися стихійно в залежності від ситуації. Отже будь-яке практичне заняття повинне мати конкретну мету.

У ході діалогового навчання студенти вчаться критично мислити, вирішувати складні проблеми на основі аналізу обставин і відповідної інформації, зважу- 
вати альтернативні думки, приймати продумані рішення, брати участь в дискусіях, спілкуватися з іншими людьми. Для цього на заняттях організовуються індивідуальна, парна і групова робота, застосовуються дослідницькі проекти, рольові ігри, йде робота 3 документами і різними джерелами інформації.

Активну пізнавальну діяльність студентів доцільно стимулювати і спрямовувати таким чином, щоб навіть в недостатньо чіткій відповіді студента на поставлене запитання викладач знаходив раціональне зерно, акцентував на ньому увагу i, тим самим, заохочував студента до подальшої активності.

Діалогове спілкування зі студентами можливе за таких умов: 1) викладач входить в діалог зі студентами як співрозмовник, колега $з$ досвідом; 2) розглянутий матеріал містить обговорення різних точок зору, підходів, вирішення спірних моментів; 3) отримане нове знання виглядає справжнім не тільки в силу авторитету викладача, а у силу доказів його істинності системою аргументів; 4) комунікація зі студентами будується таким чином, щоб підвести їх до висновків, зробити учасниками формування висновків.

Технологія впровадження інтерактивних форм навчання на кафедрі являє собою поетапне, логічно вибудуване використання форм інтерактивного навчання від найпростіших до найбільш складних і включає в себе: освоєння ігрових процедур і прийомів за допомогою введення їх в практику проведення занять, реалізованих в традиційній формі; розширення використання на заняттях ігрових ситуацій, елементів дискусій, проведення в ігровій формі заліків, захистів історій хвороб; цільову розробку ділових ігор, ігрових ситуацій.

Кожен викладач може самостійно придумати нову або удосконалити існуючу технологію роботи зі студентами. На кафедрі часто використовують технологію “Робота в парах", коли студенти вчаться ставити один одному питання і відповідати на них. Teхнологія “Акваріум” полягає в тому, що кілька студентів розігрують ситуацію в колі, а інші спостерігають і аналізують. За технологією “Дерево рішень”

\section{Література}

1. Андрущенко В. Високі педагогічні технології / В. Андрущенко, В. Олексенко // Вища освіта України. - 2007. - № 2. - C. 70-76.

2. Белокопытов Ю. Активные методы обучения / Ю. Белокопытов, Г. Панасенко // Высшее образование в России. -2004. - № 4. - C. 167-169.
- група ділиться на 2-3 групи з однаковою кількістю студентів. Кожна група обговорює питання і робить запис на своєму “дереві” (аркуш паперу), потім групи міняються місцями і дописують на деревах сусідів свої ідеї. Часто використовують і таку форму інтеракції, як “Займи позицію”. Зачитується яке-небудь твердження і студенти повинні підійти до плаката зі словом “ТАК” або "НІ". Бажано, щоб вони пояснили свою позицію.

Вміння конкретизувати і обгрунтувати мету всіх своїх дій, розвинута інтуїція, здатність до прогнозування, творчого вирішення завдань нерозривно пов'язані з навичками усного мовлення. Уміння коротко, аргументовано і послідовно представити пацієнта, чітко сформулювати цілі дослідження і лікування, обгрунтувати висновки, відстояти свою точку зору, грамотно і переконливо відповісти на питання - найважливіші складові професіоналізму лікаря, а отримувати і удосконалювати їх необхідно зі студентських років.

Виходячи 3 вищезазначеного, потрібно належну увагу приділяти розвитку навичок усного мовлення, набуття навичок спілкування 3 пацієнтом 3 метою створення психоемоційного комфорту при проведенні діагностичних та лікувально-профілактичних маніпуляцій.

Висновки：1. Таким чином, використання клінічних навчальних завдань у процесі вивчення предмета істотно збільшує багаж клінічних знань $з$ одночасним підвищенням пізнавальної здатності студентів, надає їм творчу самостійність, розширює обсяг набутих практичних навичок. Все це в кінцевому підсумку сприяє засвоєнню нових теоретичних і практичних знань, підвищує якість підготовки майбутніх лікарів.

2. Інтерактивна діяльність на заняттях передбачає організацію і розвиток діалогового спілкування, яке веде до взаєморозуміння, взаємодії, до спільного вирішення загальних, але значимих для кожного учасника завдань. Інтерактив дає можливість кожному всебічно проявити свої здібності.

3. Буряк В. Формування у студентів критичного стилю мислення / В. Буряк // Вища школа. -2007. -№ 3.-С. 21-30.

4. Корнеева Л. И. Интерактивные методы обучения / Л. И. Корнеева // Высшее образование в России. - 2004. № 12. - С. $105-108$. 